\title{
High prevalence of zoonotic trematodes in roach (Rutilus rutilus) in the Gulf of Finland
}

\author{
Anu Näreaho ${ }^{*^{*} \mathbb{D}}$, Anna Maria Eriksson-Kallio² ${ }^{2}$ Petra Heikkinen ${ }^{3}$, Anna Snellman ${ }^{1}$, Antti Sukura ${ }^{1}$ \\ and Perttu Koski
}

\begin{abstract}
The intention to increase roach (Rutilus rutilus) consumption is in focus for ecological and economic reasons in Finland. However, its safety as food has not been considered comprehensively. We collected and artificially digested 85 roach halves originating from the south-eastern coast of Finland, and found trematode metacercariae in $98.8 \%$ of the samples. Based on polymerase chain reaction (PCR) and sequencing of amplicons generated from the ITS2 gene region, zoonotic parasites of the family Opistorchiidae were identified as Pseudamphistomum truncatum and Metorchis bilis, and also non-zoonotic Holostephanus dubinini (family Cyathocotylidae) and Posthodiplostomum spp. (family Diplostomidae) were identified. The species identity of other trematodes found is currently being investigated. Mixed infections of several trematode species were common. The prevalence of morphologically identified zoonotic $P$. truncatum was $46 \%$, and zoonotic M. bilis was found in one sequence sample. The high prevalence of zoonotic trematode metacercariae in roach from the Gulf of Finland is alarming. Only thoroughly cooked roach products can be recommended for human or animal consumption from the area.
\end{abstract}

Keywords: Holostephanus dubinini, Metacercaria, Metorchis bilis, Posthodiplostomum, Pseudamphistomum truncatum, Roach, Trematode

\section{Findings}

The roach (Rutilus rutilus) is in Finland considered as a coarse fish with low commercial value. In 2015, for example, the average annual consumption of roach in Finland was only 50 g per capita (counted as fillet weight) [1]. Its removal from the water system, however, reduces the biomass and delays eutrophication, and the utilization of roach as fertilizer, in bioenergy production, as animal feed, and recently as food, has consequently been under study [2]. Interest in ecological and local food has increased and the industrial use of roach in human nutrition has been tested in Finland. Roach patties have been produced in some industrial kitchens and served in work places, schools and nursing homes. The consumption of unprocessed, raw roach in Finland is still rare, but food

\footnotetext{
${ }^{*}$ Correspondence: anu.nareaho@helsinki.fi

1 Veterinary Biosciences, University of Helsinki, P.O. Box 66, 00014 Helsinki, Finland

Full list of author information is available at the end of the article
}

trends including salt curing, raw pickling and sushi might change this.

Fishborne trematode infections are of major concern in areas of high prevalence with eating habits favouring the consumption of raw fish [3,4]. Fishborne intestinal trematodiasis is common, for example, in certain parts of Asia, and a high prevalence has been reported from Vietnam [5]. Liver flukes may cause bile duct and liver damage and even bile duct cancer $[4,6,7]$.

There have been previous observations of black spots on the skin and fins of roach caused by a bird trematode Posthodiplostomum (family Diplostomidae) in the brackish water of the Gulf of Finland, and their occurrence appears to be increasing [8]. Zoonotic Pseudamphistomum truncatum and Metorchis bilis (family Opistorchiidae) have been found in the coastal area in one of their final hosts, the fox [8]. Grey seals (Halichoerus grypus) in the Baltic Sea have also been observed to commonly carry P. truncatum $[8,9]$. High prevalence (75\%) of Pseudamphistomum truncatum in the roach in the Russian waters of the Gulf of Finland has been recently 
reported [10]. Metorchis bilis, nowadays genetically identified as a single species together with $M$. albidus and $M$. crassiusculus [11], as well as $P$. truncatum, can infect humans [12].

Due to infections in wildlife, we carried out a preliminary prevalence study on zoonotic trematodes in one of their intermediate hosts, the roach, from one location in the eastern Gulf of Finland, Baltic Sea. We also aimed to identify other trematode species existing in the area.

Roach caught by local commercial fishermen as bycatch were collected from the eastern Gulf of Finland, near the city of Kotka. They were transported to the Finnish Food Safety Authority (Evira) in Helsinki, where they were measured, weighed, gutted and filleted. Topical black spots were semi-quantified for each fish. Half of the fish, with the fins and skin included but without the head, was digested and the other half was frozen $\left(-20{ }^{\circ} \mathrm{C}\right)$ for further purposes. Altogether, 85 roach halves were digested and examined for metacercariae.

The digestion was performed in the parasite laboratory of the Faculty of Veterinary Medicine, University of Helsinki, with $\mathrm{HCl}$-pepsin digestion modified from the method described by WHO [13]. Briefly, $50 \mathrm{~g}$ or smaller fish fillet was homogenized with a kitchen grinder and $500 \mathrm{~mL}$ of artificial gastric fluid containing 1\% pepsin and $0.6 \% \mathrm{HCl}$ was added. If the fish fillet was heavier, more digestion fluid was used accordingly. The mixture was placed on a magnetic stirrer and vigorously stirred for $30 \mathrm{~min}$ at $37^{\circ} \mathrm{C}$. The digestion fluid was then sieved through a kitchen sieve with a mesh size of about $2 \mathrm{~mm}$ into a funnel and allowed to sediment for $30 \mathrm{~min}$. The sediment (about 1:5 of the original volume) was collected, mixed with tap water, sieved through a smaller mesh size $(1 \mathrm{~mm})$, and sedimented again for $15 \mathrm{~min}$. This clarification step was repeated if the fluid was still too cloudy for microscopic examination. After the final sedimentation, the sediment was collected on a petri dish with a grid drawn on the bottom and examined under a stereomicroscope. Morphologically similar metacercariae from each sample were preserved in tubes in ethanol at $-20{ }^{\circ} \mathrm{C}$ for DNA analysis.

Molecular typing was performed for 83 individual metacercariae from 31 fish. Before lysis, the excess ethanol was evaporated from each sample tube containing a single metacercaria. Lysis buffer $(10 \mathrm{mM}$ Tris ( $\mathrm{pH} 8.0)$, $1 \mathrm{mM}$ EDTA, $0.45 \%$ (v/v) Tween 20 and $60 \mu \mathrm{g} / \mathrm{mL}$ of Proteinase K) was added and incubated at $65{ }^{\circ} \mathrm{C}$ for $3 \mathrm{~h}$ or until the parasite had completely degraded. Finally, the proteinase enzyme was inactivated at $95^{\circ} \mathrm{C}$ for $10 \mathrm{~min}$.

Molecular identification was based on polymerase chain reaction (PCR) and sequencing of amplicons generated from the ITS2 gene region using previously published primers (F: 5'-CTCGGCTCGTGTGTCGATGA-3' and R: 5'-GCATGCARTTCAGCGGGTA-3') [14]. PCR was carried out in a final volume of $20 \mu \mathrm{L}$ containing $1 \times$ DyNAzyme Buffer (Finnzymes, Vantaa, Finland), $0.25 \mathrm{mM}$ dNTP (Finnzymes), $2 \mathrm{mM} \mathrm{MgCl}$, $1 \mathrm{U}$ DyNAzyme II DNA Polymerase (Finnzymes), $0.25 \mu \mathrm{M}$ of each primer and $2 \mu \mathrm{L}$ of the cell lysate. PCR was performed under the following conditions: initial denaturation at $95{ }^{\circ} \mathrm{C}$ for $5 \mathrm{~min}, 40$ cycles at $94{ }^{\circ} \mathrm{C}$ for $30 \mathrm{~s}, 55^{\circ} \mathrm{C}$ for $1 \mathrm{~min}$ and $72{ }^{\circ} \mathrm{C}$ for $1 \mathrm{~min}$, followed by a final extension of $7 \mathrm{~min}$ at $72{ }^{\circ} \mathrm{C}$. All PCR reactions were carried out in an XP Cycler (Bioer, Hangzhou, China). The PCR products were visualized in $1.5 \%$ agarose gel electrophoresis, excised, gel-purified using an E.Z.N.A. ${ }^{\circledR}$ Gel Extraction Kit (Omega Bio-tek, Norcross, GA, USA) and sequenced using ABI technology (Applied Biosystems Co., Waltham, USA). Sequencing was performed using a BigDye Terminator v3.1 Cycle Sequencing Kit (Applied Biosystems Co.) The quality of the individual electropherograms was verified visually and sequences were analysed using MEGA 6 software [15].

All but one of the examined fish (98.8\%) had trematode metacercariae in the digested half. Black spots, macroscopically typical of Posthodiplostomum species, were visually observed on $20 \%$ of the roach. The number of the metacercariae isolated from the digested halves varied from 0 to 281. The number of metacercariae per gram (mc/g) varied from 0 to $11.4 \mathrm{mc} / \mathrm{g}$ (median $0.32 \mathrm{mc} / \mathrm{g}$ ). Mixed infections with several species were common. We observed 4 morphological categories of encysted metacercariae and 3 categories of excysted metacercariae, which overlapped in sequencing. From the sequenced metacercariae, 68 samples yielded a reliable sequence. Based on the sequencing, the trematode species in roach from the Gulf of Finland included at least zoonotic $P$. truncatum and M. bilis, and non-zoonotic bird trematodes, Holostephanus dubinini (family Cyathocotylidae) and Posthodiplostomum spp. (Table 1). In addition to these, currently unidentified species were present. Pseudamphistomum truncatum (Fig. 1) was also morphologically recognizable [16], and a total prevalence of $46 \%$ was calculated for this species by combining the morphological description and the sequence data from a total of 39 fish and by omitting any uncertain identifications.

A surprisingly high prevalence of trematode metacercariae was found in roach from the eastern Gulf of Finland. The abundance of the zoonotic species (mainly Pseudamphistomum truncatum) is alarming. Because the roach is considered as an ecologically recommendable food species [17], human consumption of raw roach should be carefully considered from the zoonotic point of view. Based on these preliminary results, only highly processed roach products with no possibility of containing infective trematode metacercariae can be recommended 
Table 1 Length of the sequenced ITS2-region of the metacercariae and the correspondence to the GenBank data

\begin{tabular}{lllll}
\hline Trematode & n sequences & Sequence length & Similarity \% & Accession numbers \\
\hline P. truncatum & 23 & 388 & 100 & JF710315 \\
M. bilis & 1 & 405 & 100 & KT740982 \\
H. dubinini & 1 & 470 & 100 & AY245707 \\
Posthodiplostomum spp. & 9 & 427 & 96 & AB693170 \\
\hline
\end{tabular}

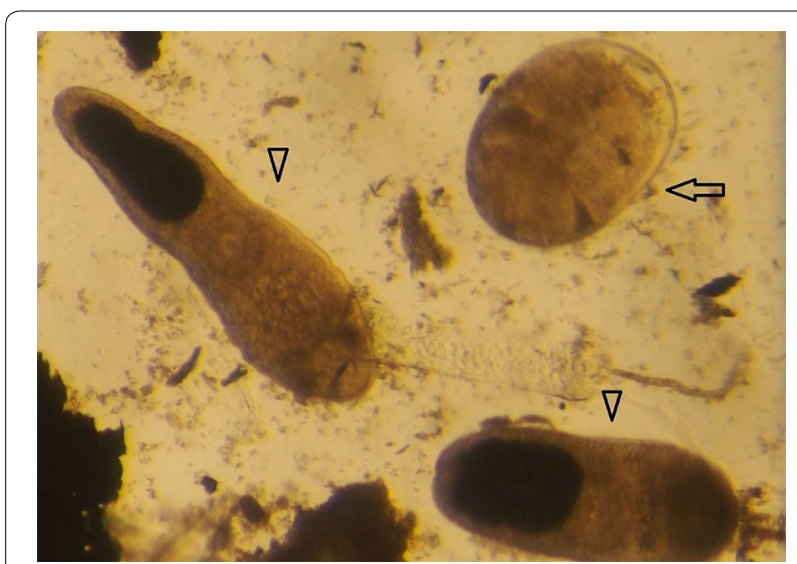

Fig. 1 One encysted (arrow) and two excysted Pseudamphistomum truncatum metacercariae (arrowheads) in digestion fluid for human consumption or as animal feed. To date, no surveys on risk populations have been carried out, and no data are available on human or companion animal exposure. Until further investigations are carried out, all raw roach should be considered as risk material for humans and fish-eating pets, such as dogs and cats. In Ireland P. truncatum has been found in mink and Eurasian otter [18], and in Denmark in both roach and mink close to Copenhagen city centre, where concern over human health was also raised [16].

Future research in Finland should include: (1) species identification of all the roach trematodes found, (2) identification of their local definitive hosts and determining the prevalence in the first intermediate hosts (gastropods), which maintain the life cycle of the parasites, (3) evaluation of the health risks to humans and pets in the highly endemic area and (4) a wider investigation of the distribution of trematodes in the Baltic Sea coast as well as in the Finnish lakes and rivers.

\section{Abbreviations}

dNTP: deoxynucleotide triphosphate; $\mathrm{HCl}$ : hydrochloric acid; ITS: internal transcribed spacer; mc/g: metacercariae per gram; MgCl2: magnesium chloride; PCR: polymerase chain reaction.

\section{Authors' contributions}

AN co-planned the study and methodology, supervised the undergraduate student (ASne) in the laboratory, performed part of the morphological analysis and was a major contributor in writing the manuscript. AME-K co-planned the study and methodology, was the contact person for the fishermen, supervised the undergraduate student (ASne) in the necropsy, and participated in writing the manuscript. PH set up and performed the molecular diagnostics and described it in the manuscript. ASne performed the fish preparation, digestion and part of the morphological analysis. ASu and PK co-planned the study and participated in writing the manuscript. All authors read and approved the final manuscript.

\section{Author details}

${ }^{1}$ Veterinary Biosciences, University of Helsinki, P.O. Box 66, 00014 Helsinki, Finland. ${ }^{2}$ Finnish Food Safety Authority Evira, Mustialankatu 3, 00790 Helsinki, Finland. ${ }^{3}$ Finnish Food Safety Authority Evira, Elektroniikkatie 3, 90590 Oulu, Finland.

\section{Acknowledgements}

We thank the Federation of Sea Fishers in Southern Finland, especially Teemu Tast, for cooperation and for the fish analyzed in the study.

\section{Competing interests}

The authors declare that they have no competing interests.

\section{Availability of data and materials}

These are available from the corresponding author on reasonable request.

\section{Consent for publication}

Consent for publication is from all the authors. No other parties are involved.

\section{Ethics approval and consent to participate}

Because the fish were sampled from the by-catch of commercial fishermen, no ethical permission was required.

\section{Funding}

No external funding was applied for or used.

\section{Publisher's Note}

Springer Nature remains neutral with regard to jurisdictional claims in published maps and institutional affiliations.

Received: 10 May 2017 Accepted: 22 October 2017

Published online: 01 November 2017

\section{References}

1. Natural Resources Institute Finland. Statistics database: domestic fish consumption in 2015 by origin. http://statdb.luke.fi/PXWeb/ pxweb/en/LUKE/LUKE_06\%20Kala\%20ja\%20riista_06\%20 Muut_02\%20Kalan\%20kulutus/4_Kotimaisen_kalankulutus.px/table/ tableViewLayout1/?rxid=dc711a9e-de6d-454b-82c2-74ff79a3a5e0. Accessed 6 Oct 2017.

2. Jay C, Koistinen K. Eläinperäisen biomassanpoiston hyödyntäminen Itämeren rehevöitymisen hidastamisessa (In Finnish). Lappeenranta University of Technology, School of Energy Systems, Scientific and 
Expertise Publications, 2015. https://www.doria.fi/bitstream/handle/10024/104850/NUTS-typenkierto-biomassanpoisto\%20kansilla. pdf?sequence $=2$. Accessed 6 Oct 2017.

3. Dung D, Van De N, Waikagul J, Dalsgaard A, Chai J-Y, Sohn W-M, Murrell D. Fishborne zoonotic intestinal trematodes, Vietnam. Emerg Infect Dis. 2007;13:1828-33.

4. Petney T, Andrews R, Saijuntha W, Wenz-Mücke A, Sithithaworn P. The zoonotic, fish-borne liver flukes Clonorchis sinensis, Opisthorchis felineus and Opisthorchis viverrini. Int J Parasitol. 2013;43:1031-46.

5. Phan TV, Ersbøøll AK, Nguyen KV, Madsen H. Dalsgaard A Farm-level risk factors for fish-borne zoonotic trematode infection in integrated smallscale fish farms in northern Vietnam. PLoS Negl Trop Dis. 2010. https:// doi.org/10.1371/journal.pntd.0000742.

6. Choi B, Han J, Hong S, Lee K. Clonorchiasis and Cholangiocarcinoma: etiologic relationship and imaging diagnosis. Clin Microbiol Rev. 2004; 17:540-52.

7. Lim J. Liver flukes: the malady neglected. Korean J Radiol. 2011;12:269-79.

8. Finnish Food Safety Authority, Evira. https://www.evira.fi/tietoa-evirasta/ ajankohtaista/2017/ihmiseen-tarttuvia-maksamatoja-suomenlahdensarjissa/ (In Finnish). Published 3rd April 2017. Accessed 6 Oct 2017.

9. Neimanis AS, Moraeus C, Bergman A, Bignert A, Höglund J, Lundström K, et al. Emergence of the zoonotic biliary trematode Pseudamphistomum truncatum in grey seals (Halichoerus grypus) in the Baltic Sea. PLoS ONE. 2016;1 :e0164782.

10. Voronin V, Belova L, Kudriavceva T, Krotov V, Portnova E, Baeva E. Infestation of cyprinide fishes with metacercariae Pseudamphistomum truncatum (Rudolphi, 1819) in the Gulf of Vyborg, Leningrad region. Veterinarya. 2017;3:38-42 (In Russian, abstract in English)

11. Sitko J, Bizos J, Sherrard-Smith E, Stanton D, Komorová P, Heneberg P. Integrative taxonomy of European parasitic flatworms of the genus Metorchis Looss, 1899 (Trematoda: Opisthorchiidae). Parasitol Int. 2016;65:258-67.

12. Hung N, Madsen $H$, Fried B. Invited review: global status of fish-borne zoonotic trematodiasis in humans. Acta Parasitol. 2013;58:231-58.

13. World Health Organization, Geneva Switzerland. Control of foodborne trematode infections. World Health Organ Tech Rep Ser. 849, Annex 6, 1995. 849:1-157.

14. Müller B, Schmidt J, Mehlhorn H. PCR diagnosis of infections with different species of Opisthorchiidae using a rapid clean-up procedure for stool samples and specific primers. Parasitol Res. 2007;100:905-9.

15. Tamura K, Stecher G, Peterson D, Filipski A, Kumar S. MEGA6: molecular evolutionary genetics analysis version 6.0. Mol Biol Evol. 2013;30:2725-9.

16. Skov J, Kania P, Jørgensen T, Buchmann K. Molecular and morphometric study of metacercariae and adults of Pseudamphistomum truncatum (Opisthorchiidae) from roach (Rutilus rutilus) and wild American mink (Mustela vison). Vet Parasitol. 2008;155:209-16.

17. Eskelinen $\mathrm{P}$, Ahvonen A, Auvinen $\mathrm{H}$, Heikinheimo O, Moilanen $\mathrm{P}$, Mäki-Petäys A, et al. Hobby fisheries in Finland (In Finnish). Report RKTL:n työraportteja 6/2013. https://jukuri.luke.fi/bitstream/handle/10024/520134/rktltr2013_6.pdf?sequence=1. Accessed 6 Oct 2017.

18. Hawkins C, Caffrey J, Stuart P, Lawton C. Biliary parasite Pseudamphistomum truncatum (Opistorchiidae) in American mink (Mustela vison) and Eurasian otter (Lutra lutra) in Ireland. Parasitol Res. 2010;107:993-7.

\section{Submit your next manuscript to BioMed Central and we will help you at every step:}

- We accept pre-submission inquiries

- Our selector tool helps you to find the most relevant journal

- We provide round the clock customer support

- Convenient online submission

- Thorough peer review

- Inclusion in PubMed and all major indexing services

- Maximum visibility for your research

Submit your manuscript at www.biomedcentral.com/submit 